\title{
Uji Daya Hasil 10 Hibrida Harapan Jagung Madura Berdaya Hasil Tinggi dan Berumur Genjah
}

\author{
Yield Evaluation of Ten "Madura” Promosing Hybrid Mayze with High Productivity and Early Maturity
}

\author{
Achmad Amzeri ${ }^{1 *}$ \\ Program Studi Agroteknologi Fakultas Pertanian Universitas Trunojoyo Madura \\ Jl. Raya Telang PO BOX 2 Kamal Bangkalan Madura \\ Email : aamzeri@gmail.com
}

Diterima 12 Januari 2017/ Disetujui 3 Maret 2017

\begin{abstract}
Improvement of potensial hybrid maize varieties that have high production potential and early maturity needed to overcome the problems of conditions of Madura agricultural land which has a water availability and low rainfall. The objective of this research was to evaluate yield potential of 10 promosing hybrids of Madura maize from Faculty of agriculture, University Trunojoyo of Madura. This research was conducted at experimental station Agrotechnology Study Program, Faculty of Agriculture, University Trunojoyo of Madura, from February to November 2015. The genotypes used were : $M H-3, M H-4, M H-5, M H-6, M H-8, M H-9, M H-11, M H-14, M H-15, M H-15$ and three hybrid varieties i.e. Bima Provit A-1, Bima $13 Q$ and BISI-2. The design of this research was randomized block design with four replications. Data was analyzed with $F$-test then continued with Duncan's test $(\alpha=5 \%)$. The combined analysis is used to determine the interaction between the genotype with the seasons and estimate the heritability in a broad sense. Selection index was used for choosing the best genotype. The results from this research showed that 10 Promosing Hybrids of Madura Maize has a different appearance, harvesting, production potential which is different from the three comparison varieties. The test results combined in two seasons shows that there is interaction between the genotype with the season on the character cob length, weight of 100 seeds, and yield per hectare. Heritability in the broad sense of maize genotype for the characters evaluated ranged from 0,22 - 0,61. The results of the selection index value indicates that promosing hybrids of Madura maize that have the highest index of selection were $\mathrm{MH}-3$ and $\mathrm{MH}-4$ and can be developed into a Madura commercial hybrid varieties.
\end{abstract}

Keywords : board sense heritability, index selection, promosing hybrids of Madura maize, yield trial

\section{ABSTRAK}

Perakitan varietas jagung hibrida unggul Madura yang mempunyai potensi produksi tinggi dan berumur genjah dibutuhkan untuk mengatasi permasalahan kondisi lahan pertanian Madura yang mempunyai ketersediaan air dan curah hujan rendah. Tujuan penelitian ini adalah untuk mengevaluasi daya hasil 10 jagung hibrida harapan Madura koleksi Fakultas Pertanian Universitas Trunojoyo Madura. Penelitian ini dilaksanakan di Kebun Percobaan Program Studi Agroteknologi Fakultas Pertanian Universitas Trunojoyo Madura, yang dilaksanakan dari bulan Februari sampai bulan November 2015. Genotip yang digunakan adalah $M H-3, M H-4, M H-5, M H-6, M H-8, M H-9, M H-11, M H-14, M H-15, M H-15$ dan 3 varietas jagung hibrida pembanding yaitu Bima Provit A-1, Bima 13Q dan BISI-2. Rancangan yang digunakan pada penelitian ini adalah Rancangan Acak Kelompok dengan empat ulangan. Data dianalisis dengan uji-F, kemudian dilanjutkan dengan uji Duncan's $(\alpha=5 \%)$. Analisis gabungan digunakan untuk mengetahui interaksi antara genotip dengan musim dan menduga nilai heritabilitas dalam arti luas. Seleksi indeks digunakan untuk memilih jagung hibrida harapan yang terbaik. Hasil penelitian menunjukkan bahwa sepuluh jagung hibrida harapan yang diuji memiliki perbedaan penampilan, umur panen, potensi produksi yang berbeda dengan tiga varietas pembanding. Hasil pengujian gabungan pada dua musim menunjukkan bahwa ada interaksi antara perlakuan genotip dengan musim pada karakter panjang tongkol, bobot 100 biji, dan produksi per hektar. Nilai heritabilitas dalam arti luas genotip jagung untuk karakter yang dievaluasi berkisar antara 22 - 61\%. Hasil nilai seleksi indeks menunjukkan bahwa jagung hibrida harapan Madura yang memiliki seleksi indeks tertinggi adalah MH-3 dan MH-4 dan dapat dikembangkan menjadi varietas hibrida Madura komersial.

Kata kunci : heritabilitas dalam arti luas, jagung hibrida harapan Madura, seleksi indeks, uji daya hasil.

\section{PENDAHULUAN}

Pulau Madura merupakan suatu pulau yang berada di wilayah Jawa Timur yang memiliki areal tanaman untuk jagung kurang lebih 360.000 hektar (30\% areal jagung di Jawa Timur), namun produktivitas ditingkat petani masih rendah rata-rata 1,4 ton per hektar (Roesmarkam et al., 2006; Kasryno et al., 2007). Hasil tersebut sangat rendah dibandingkan dengan daerah-daerah 
penghasil jagung lainnya. Rendahnya produksi jagung ditingkat petani tersebut disebabkan oleh kurang suburnya lahan, curah hujan yang cenderung rendah dan sebagian besar benih yang digunakan bukan hasil dari program pemuliaan (baik melalui seleksi atau hibridisasi). Menurut data BPS (2013), bahwa ratarata produktivitas jagung di daerah Jawa Timur berkisar 4,8 ton per hektar, sehingga produktivitas tanaman jagung di Madura masih perlu ditingkatkan.

Rendahnya produksi jagung ditingkat petani tersebut disebabkan oleh kurang suburnya lahan, curah hujan yang cenderung rendah dan sebagian besar benih yang digunakan bukan hasil dari program pemuliaan (baik melalui seleksi atau hibridisasi). Terdapat beberapa cara untuk memecahkan permasalahan tersebut, diantaranya adalah (1) memperbaiki lingkungan tempat tanaman tersebut tumbuh dan berkembang, (2) merakit suatu varietas yang tahan terhadap cekaman lingkungan biotik maupun abiotik dan mempunyai potensi hasil tinggi yang dihasilkan melalui program pemuliaan. Perbaikan lingkungan tumbuh membutuhkan biaya tidak sedikit, meskipun hal itu dapat dilakukan, namun ada beberapa faktor alam yang tidak bisa dikendalikan melalui teknologi yaitu cuaca dan iklim, sehingga perakitan varietas unggul yang mempunyai potensi hasil tinggi dan tahan terhadap cekaman lingkungan biotik serta abiotik merupakan solusi tepat untuk mengatasi permasalahan tersebut.

Menurut Amzeri (2015), bahwa untuk merakit suatu varietas membutuhkan strategi dalam pemuliaan tanaman agar varietas yang diinginkan dapat tercapai, diantaranya (1) pengenalan tanaman (karakterisasi tanaman), (2) pemilihan bahan pemuliaan (breeding materials), (3) pengenalan pola atau metode pemuliaan yang dipilih, dan (4) pengelolaan. Pembentukan jagung hibrida merupakan salah satu merupakans alah satu metode umum dalam pemuliaan jagung. Jagung hibrida adalah generasi F1 yang diperoleh dari hasil persilangan galur-galur inbrida.

Penampilan tanaman tergantung kepada genotip, lingkungan, dan interaksi antara genotip dan lingkungan (GxL) (Trustinah dan Iswanto, 2013). Sebelum suatu galur harapan dilepas menjadi suatu varietas, terlebih dahulu diadakan pengujian adaptasi di berbagai lokasi, musim, atau tahun. Pengujian ini dimaksudkan untuk melihat kemampuan tumbuh tanaman terhadap lingkungan dibandingkan dengan varietas unggul yang sudah ada. Stabilitas fenotip tanaman disebabkan oleh kemampuan tanaman untuk dapat menyesuaikan diri terhadap lokasi yang beragam, sehingga tanaman tidak banyak mengalami perubahan fenotip.

Uji daya hasil hibrida-hibrida harapan jagung Madura perlu dilakukan untuk mendapatkan jagung hibrida yang memiliki potensi hasil dan kualitas yang baik serta stabil pada kondisi lingkungan yang berbeda. Hibrida-hibrida harapan tersebut dapat dikembangkan menjadi varietas baru. Tujuan penelitian ini adalah mengevaluasi 10 jagung hibrida harapan Madura yaang terpilih hasil seleksi, dan mendapatkan jagung hibrida harapan Madura yang memiliki daya hasil dan kualitas hasil yang tinggi dan lebih baik daripada varietas pembanding.

\section{BAHAN DAN METODE}

Penelitian ini dimulai bulan Februari - November 2015. Penelitian dilakukan di Kebun Percobaan Agroteknologi Fakultas
Pertanian Universitas Trunojoyo Madura. Lokasi penelitian berada pada ketinggian 4 mdpl dengan jenis tanah grumosol.

Bahan tanaman yang digunakan dalam penelitian ini adalah 10 hibrida Madura harapan hasil seleksi dalam program pemuliaan, yaitu : MH-3, MH-4, MH-5, MH-6, МH-8, MH-9, MH-11, MH14, MH-15 dan MH-17. Untuk varietas pembanding, digunakan varietas jagung hibrida yaitu : Bima Provit A-1, Bima 13Q, dan BISI-2. Pupuk yang digunakan adalah pupuk Urea dengan dosis $300 \mathrm{~kg} / \mathrm{ha}$ dan Phonska dengan dosis $300 \mathrm{~kg} / \mathrm{ha}$. Pestisida yang digunakan adalah Furadan 3G, Calaris 50 EC dan Saromyl 35 SD.

Penelitian ini menggunakan Rancangan Acak Kelompok non faktorial dengan satu perlakuan yaitu genotip. Perlakuan terdiri dari 10 jagung hibrida harapan Madura dan 3 varietas pembanding, masing-masing diulang sebanyak 4 kali, sehingga terdapat 52 satuan percobaan. Setiap satuan percobaan terdiri dari 100 tanaman. Parameter pengamatan dalam penelitian ini adalah tinggi tanaman, tinggi tongkol utama, diameter batang, umur muncul tassel, umur muncul rambut, umur panen, bobot 4 tongkol, bobot 4 biji tongkol, panjang tongkol, diameter tongkol, jumlah baris biji tongkol, jumlah biji per baris, bobot 100 biji, dan produksi perhektar.

Uji F digunakan untuk menganalisis pengaruh perlakuan. Apabila terdapat pengaruh yang nyata dalam perlakuan, maka dilakukan uji lanjut menggunakan uji Duncan pada taraf $5 \%$. Analisis gabungan digunakan untuk mengetahui interaksi antara genotip dengan musim dan menduga nilai heritabilitas dalam arti luas.

Untuk menentukan urutan 10 hibrida harapan jagung Madura yang mempunyai seleksi indeks yang tinggi digunakan model (Falconer, 1964) sebagai berikut :

$\mathrm{I}=\mathrm{b} 1 \mathrm{P} 1+\mathrm{b} 2 \mathrm{P} 2+\ldots \ldots \ldots \ldots \ldots$. , dimana:

$\mathrm{I}=$ Nilai seleksi indeks total suatu genotip

$\mathrm{b}=$ Faktor pembobot masing-masing karakter

$\mathrm{P}=$ Nilai fenotipe yang telah distandarisasi dari suatu karakter yang diamati

Nilai fenotip yang telah distandarisasi dari suatu karakter yang diamati, dihitung menggunakan rumus standarisasi sebagai berikut:

$$
\begin{aligned}
& \mathrm{P}=\frac{X-\ddot{X}}{\sigma \mathrm{x}} \\
& \mathrm{x}=\text { Nilai tengah karakter dari suatu genotip } \\
& \ddot{X}=\text { Nilai tengah karakter dari total seluruh genotip } \\
& \sigma_{\mathrm{x}}=\text { Simpangan baku. }
\end{aligned}
$$

\section{HASIL DAN PEMBAHASAN}

Hasil rekapitulasi sidik ragam pada berbagai karakter menunjukkan bahwa beberapa genotip yang diuji berpengaruh nyata terhadap tinggi tanaman, tinggi tongkol utama, diameter batang, umur muncul rambut, umur panen, panjang tongkol, diameter tongkol, dan produksi per hektar. Pada karakter umur muncul tassel, bobot 4 tongkol, bobot 4 biji tongkol, jumlah baris biji tongkol, jumlah baji per baris dan bobot 100 biji tidak berpengaruh nyata (Tabel 1). 
Tabel 1. Rekapitulasi Uji F berbagai parameter pengamatan

\begin{tabular}{lll}
\hline Karakter & KT & KK (\%) \\
\hline Tinggi tanaman & $2490,20 * *$ & 15,22 \\
Tinggi tongkol utama & $226,31 * *$ & 8,33 \\
Diameter batang & $5,73 * *$ & 10,22 \\
Umur muncul tassel & $18,90 \mathrm{tn}$ & 7,21 \\
Umur muncul rambut & $60,20 *$ & 12,45 \\
Umur panen & $354,12 * *$ & 12,87 \\
Bobot 4 tongkol & $1163,00 \mathrm{tn}$ & 11,43 \\
Bobot 4 biji tongkol & $124,00 \mathrm{tn}$ & 5,88 \\
Panjang tongkol & $35,73 *$ & 5,60 \\
Diameter tongkol & $61,05 * *$ & 3,12 \\
Jumlah baris biji tongkol & $44,38 \mathrm{tn}$ & 1,21 \\
Jumlah biji per baris & $26,70 \mathrm{tn}$ & 10,21 \\
Bobot 100 biji & $24,18 \mathrm{tn}$ & 11,41 \\
Produksi per hektar & $24,71 * *$ & 9,51 \\
\hline
\end{tabular}

Keterangan : $*$ = berbeda nyata pada taraf $5 \% ; * *=$ berbeda nyata pada taraf $1 \%$.

\section{Tinggi Tanaman, Tinggi Tongkol Utama, Diameter Batang, Umur Muncul Tassel, Umur Muncul Rambut, dan Umur Panen}

Tinggi tanaman dan tinggi tongkol utama dilakukan pada saat tanaman memasuki fase generatif. Tinggi tanaman jagung hibrida harapan Madura MH-5 mempunyai tinggi tanaman terpendek dibandingkan dengan jagung hibrida harapan Madura yang lain tetapi tidak berbeda nyata dengan jagung hibrida harapan Madura yang lain yaitu MH-6, MH-11, MH-14, MH-15, MH-17, dan varietas pembanding Bima Provit A-1. Jagung hibrida harapan Madura MH-3 mempunyai tinggi tanaman tertinggi dibandingkan jagung hibrida harapan Madura yang lain, tetapi lebih rendah dibandingkan varietas pembanding BISI-2. Tinggi tongkol utama jagung hibrida harapan Madura MH-5 terpendek dibandingkan dengan jagung hibrida harapan lainnya, namun tidak berbeda nyata dengan hibrida Madura lainnya yaitu MH-6, MH-11, MH-14, MH-15, dan varietas pembanding Bima Provit A-1. Jagung hibrida harapan Madura MH-3 mempunyai tinggi tongkol utama tertinggi dibanding hibrida harapan Madura lainnya, tetapi tidak berbeda nyata dengan jagung hibrida harapan Madura MH-4, MH-8, MH-9, varietas pembanding Bima 13Q, dan lebih rendah dibandingkan dengan varietas pembanding BISI2 (Tabel 2).

Diameter tinggi batang jagung hibrida harapan Madura MH-5 dan MH-11 mempunyai diameter batang paling kecil tetapi tidak berbeda nyata pada semua hibrida harapan Madura yang diuji. Varietas pembanding BISI-2 mempunyai diameter batang paling besar di antara jagung hibrida harapan Madura dan varietas pembanding yang lain.

Umur muncul tassel dan umur muncul tassel dapat mempengaruhi umur panen jagung. Umur muncul tassel tidak berbeda nyata di antara hibrida harapan yang diuji dan varietas pembanding. Umur muncul rambut jagung hibrida harapan Madura MH-5 mempunyai umur munculnya rambut paling pendek, tetapi tidak berbeda nyata dengan jagung hibrida harapan Madura lainnya (kecuali MH-11) dan varietas pembanding Bima Provit A-1. Umur panen jagung hibrida harapan Madura MH-5 mempunyai umur panen terpendek namun tidak berbeda nyata dengan jagung hibrida harapan Madura MH-4, MH-14, MH-15, MH-17, dan varietas pembanding Bima Provit A-1.

\section{Bobot 4 tongkol, bobot 4 biji tongkol, panjang tongkol,} dan diameter tongkol

Bobot 4 tongkol dan bobot 4 biji tongkol tidak berbeda nyata di antara jagung hibrida harapan Madura dan varietas pembanding. Hibrida harapan Madura MH-6 mempunyai panjang tongkol terpendek di antara hibrida harapan Madura yang diuji tetapi tidak berbeda nyata dengan jagung hibrida harapan Madura MH-5 dan MH-9. Jagung hibrida harapan Madura MH-3 mempunyai tongkol terpanjang di antara jagung hibrida harapan Madura lainnya tetapi tidak berbeda nyata dengan jagung hibrida harapan Madura MH-4, MH-8, MH-14, MH-17 dan varietas pembanding yaitu Bima 13Q dan BISI-2 (Tabel-3). Jagung hibrida harapan Madura MH-6 mempunyai diameter tongkol paling kecil dibandingkan dengan hibrida harapan lainnya tetapi tidak berbeda nyata dengan jagung hibrida harapan Madura MH-5, MH-8, MH-9, MH-11, MH-14, MH-15, MH-17 dan varietas pembanding Bima 13Q. Diameter tongkol jagung hibrida harapan Madura MH-3 mempunyai diameter tongkol terbesar di antara hibrida harapan Madura yang diuji dan tidak berbeda nyata dengan varietas pembanding Bima Provit A-1, Bima 13Q dan BISI-2.

\section{Jumlah baris biji tongkol, jumlah biji per baris, bobot 100 biji, dan produksi per hektar}

Karakter jumlah baris biji per tongkol, jumlah biji per baris, dan bobot 100 biji tidak berbeda nyata di antara jagung harapan hibrida Madura yang diuji dan varietas pembandingan. Jagung hibrida harapan Madura MH-3 mempunyai produksi per hektar tertinggi di antara jagung hibrida harapan Madura yang lain, tetapi tidak berbeda nyata 
Tabel 2. Nilai tengah tinggi tanaman, tinggi tongkol, umur muncul tassel, umur muncul rambut, dan umur panen 10 hibrida harapan dengan tiga varietas pembanding

\begin{tabular}{|c|c|c|c|c|c|c|c|c|c|c|c|}
\hline \multirow{2}{*}{$\begin{array}{l}\text { Hibrida Harapan } \\
\text { MH-3 }\end{array}$} & \multicolumn{2}{|c|}{$\begin{array}{l}\text { Tinggi Tanaman } \\
(\mathrm{cm})\end{array}$} & \multicolumn{2}{|c|}{$\begin{array}{l}\text { Tinggi Tongkol } \\
\text { Utama (cm) }\end{array}$} & \multicolumn{2}{|c|}{$\begin{array}{c}\text { Diameter } \\
\text { Batang }(\mathrm{cm})\end{array}$} & \multirow[t]{2}{*}{$\begin{array}{c}\text { Umur } \\
\text { Muncul } \\
\text { Tassel } \\
\text { (HST) } \\
40,32 \text { a }\end{array}$} & \multicolumn{2}{|c|}{$\begin{array}{l}\text { Umur } \\
\text { Muncul } \\
\text { Rambut } \\
\text { (HST) }\end{array}$} & \multicolumn{2}{|c|}{$\begin{array}{l}\text { Umur Panen } \\
\text { (HST) }\end{array}$} \\
\hline & 193,22 & $\mathrm{e}$ & 94,21 & e & 3,61 & $a b c$ & & 43,41 & $a b c$ & 86,46 & bcd \\
\hline $\mathrm{MH}-4$ & 181,13 & $d$ & 89,92 & de & 3,44 & $\mathrm{ab}$ & $38,64 \mathrm{a}$ & 41,84 & $\mathrm{a}$ & 85,97 & abcd \\
\hline MH-5 & 154,21 & $\mathrm{a}$ & 72,31 & $\mathrm{a}$ & 3,42 & $\mathrm{a}$ & $38,12 \mathrm{a}$ & 41,22 & $\mathrm{a}$ & 80,21 & $\mathrm{a}$ \\
\hline MH-6 & 161,34 & $a b$ & 78,14 & $a b c$ & 3,44 & $a b$ & $40,23 \mathrm{a}$ & 43,16 & $a b c$ & 90,21 & d \\
\hline MH-8 & 175,92 & bcd & 86,31 & cde & 3,42 & $\mathrm{a}$ & $42,31 \mathrm{a}$ & 45,23 & $a b c$ & 89,32 & $\mathrm{~d}$ \\
\hline МH-9 & 178,10 & $\mathrm{~cd}$ & 87,76 & cde & 3,57 & $a b$ & $43,55 \mathrm{a}$ & 46,45 & $a b c$ & 90,31 & d \\
\hline MH-11 & 163,25 & $\mathrm{ab}$ & 75,33 & $a b$ & 3,42 & $\mathrm{a}$ & $44,91 \mathrm{a}$ & 47,86 & bc & 90,54 & $\mathrm{~d}$ \\
\hline MH-14 & 165,52 & $a b c$ & 76,49 & $\mathrm{ab}$ & 3,43 & $\mathrm{a}$ & $41,42 \mathrm{a}$ & 43,91 & $a b c$ & 83,26 & $a b c$ \\
\hline MH-15 & 160,24 & $a b$ & 80,91 & abcd & 3,55 & $a b$ & $40,22 \mathrm{a}$ & 43,94 & $a b c$ & 81,52 & $a b$ \\
\hline MH-17 & 165,19 & $a b c$ & 82,71 & bcd & 3,51 & $a b$ & $39,34 \mathrm{a}$ & 42,96 & $a b$ & 81,97 & $a b$ \\
\hline Bima Provit A-1 & 165,21 & $a b c$ & 73,53 & $a b$ & 3,57 & $a b$ & $39,21 \mathrm{a}$ & 41,41 & $\mathrm{a}$ & 80,62 & $\mathrm{a}$ \\
\hline Bima 13Q & 191,00 & de & 94,82 & $\mathrm{e}$ & 3,78 & $\mathrm{bc}$ & $45,75 \mathrm{a}$ & 48,98 & $\mathrm{c}$ & 87,68 & $\mathrm{~cd}$ \\
\hline BISI-2 & 221,11 & $\mathrm{f}$ & 114,21 & $\mathrm{f}$ & 3,82 & $\mathrm{c}$ & $52,28 \mathrm{a}$ & 55,42 & $\mathrm{~d}$ & 103,20 & $\mathrm{e}$ \\
\hline
\end{tabular}

Keterangan: Angka dalam satu kolom diikuti oleh huruf yang sama tidak berbeda nyata pada berdasarkan uji Duncan's pada $\operatorname{taraf} 5 \%$.

Tabel 3. Nilai tengah bobot 4 tongkol, bobot 4 biji tongkol, panjang tongkol, dan diameter tongkol 10 hibrida harapan dengan tiga varietas pembanding

\begin{tabular}{|c|c|c|c|c|c|}
\hline Hibrida Harapan & $\begin{array}{c}\text { Bobot } 4 \text { tongkol } \\
(\mathrm{g})\end{array}$ & $\begin{array}{c}\text { Bobot } 4 \text { biji } \\
\text { tongkol } \\
(\mathrm{g})\end{array}$ & $\begin{array}{l}\text { Panjang tongkol } \\
(\mathrm{g})\end{array}$ & \multicolumn{2}{|c|}{$\begin{array}{c}\text { Diameter tongko } \\
(\mathrm{g})\end{array}$} \\
\hline MH-3 & $699,42 \mathrm{a}$ & $551,51 \mathrm{a}$ & $23,91 \mathrm{~d}$ & 4,95 & $\mathrm{c}$ \\
\hline MH-4 & $691,51 \mathrm{a}$ & $542,43 \mathrm{a}$ & $22,92 \mathrm{~cd}$ & 4,63 & $\mathrm{bc}$ \\
\hline MH-5 & $684,54 \mathrm{a}$ & $540,25 \mathrm{a}$ & $20,46 \mathrm{ab}$ & 4,22 & $a b$ \\
\hline MH-6 & $683,42 \mathrm{a}$ & $539,92 \mathrm{a}$ & $19,51 \mathrm{a}$ & 4,17 & $\mathrm{a}$ \\
\hline MH-8 & $690,44 \mathrm{a}$ & $544,68 \mathrm{a}$ & $22,53 \mathrm{~cd}$ & 4,55 & $a b c$ \\
\hline MH-9 & $686,99 \mathrm{a}$ & $543,63 \mathrm{a}$ & $22,19 \mathrm{ab}$ & 4,53 & $a b c$ \\
\hline MH-11 & $685,82 \mathrm{a}$ & 544,46 a & $21,72 \mathrm{bc}$ & 4,24 & $a b$ \\
\hline MH-14 & $689,51 \mathrm{a}$ & $543,91 \mathrm{a}$ & $22,14 \mathrm{~cd}$ & 4,59 & $a b c$ \\
\hline MH-15 & $688,35 \mathrm{a}$ & $544,58 \mathrm{a}$ & $21,87 \mathrm{bc}$ & 4,52 & $a b c$ \\
\hline MH-17 & $690,96 \mathrm{a}$ & $545,66 \mathrm{a}$ & $22,51 \mathrm{~cd}$ & 4,53 & $a b c$ \\
\hline Bima Provit A-1 & $688,43 \mathrm{a}$ & $543,92 \mathrm{a}$ & $21,45 \mathrm{bc}$ & 4,61 & $\mathrm{bc}$ \\
\hline Bima 13Q & $691,48 \mathrm{a}$ & 545,98 a & $22,53 \mathrm{~cd}$ & 4,55 & $a b c$ \\
\hline BISI-2 & $699,52 \mathrm{a}$ & $555,31 \mathrm{a}$ & $22,99 \mathrm{~cd}$ & 4,97 & $\mathrm{c}$ \\
\hline
\end{tabular}

Keterangan : Angka dalam satu kolom diikuti oleh huruf yang sama tidak berbeda nyata pada berdasarkan uji Duncan's pada taraf $5 \%$.

\section{Analisis Gabungan Dua Musim}

Hasil analisis gabungan (Tabel 5) menunjukkan bahwa perlakuan genotip berpengaruh nyata terhadap karakter tinggi tanaman, peubah bobot tongkol tanpa kelobot per plot, tinggi tanaman, kadar PTT, tinggi tongkol utama, diameter batang, umur muncul rambut, umur panen, bobot 4 tongkol, panjang tongkol, diameter tongkol, bobot 100 biji, dan produksi per hektar. Perlakuan musim berpengaruh nyata terhadap semua parameter yang diamati. Interaksi antara genotip dengan musim berpengaruh nyata terhadap karakter panjang tongkol, bobot 100 biji, dan produksi per hektar, tetapi tidak berpengaruh nyata terhadap peubah lainnya. Interaksi genotip dan lingkungan yang nyata akan mempengaruhi penampilan fenotip tanaman. Hal ini berarti genotip yang sama akan memberikan respon pertumbuhan yang berbeda pada musim yang berbeda. 
Tabel 4. Nilai tengah jumlah baris biji tongkol, jumlah biji per baris, bobot 100 biji dan produksi per hektar 10 hibrida harapan dengan tiga varietas pembanding

\begin{tabular}{|c|c|c|c|c|c|}
\hline Genotip & $\begin{array}{c}\text { Jumlah Baris Biji } \\
\text { Tongkol (baris) }\end{array}$ & $\begin{array}{l}\text { Jumlah Biji per Baris } \\
\text { (Biji) }\end{array}$ & $\begin{array}{c}\text { Bobot } 100 \text { Biji } \\
(\mathrm{g})\end{array}$ & \multicolumn{2}{|c|}{$\begin{array}{l}\text { Produksi per Hektar } \\
\text { (ton/hektar) }\end{array}$} \\
\hline $\mathrm{MH}-3$ & $13,41 \mathrm{a}$ & $38,25 \mathrm{a}$ & $33,19 \mathrm{a}$ & 8,23 & $\mathrm{c}$ \\
\hline MH-4 & $12,32 \mathrm{a}$ & $36,22 \mathrm{a}$ & $31,14 \mathrm{a}$ & 7,84 & bc \\
\hline MH-5 & $12,75 \mathrm{a}$ & $35,17 \mathrm{a}$ & $30,25 \mathrm{a}$ & 7,69 & bc \\
\hline MH-6 & $12,97 \mathrm{a}$ & $35,21 \mathrm{a}$ & 29,16 a & 6,74 & $\mathrm{a}$ \\
\hline MH-8 & $12,82 \mathrm{a}$ & $36,13 \mathrm{a}$ & $30,43 \mathrm{a}$ & 6,96 & $a b$ \\
\hline MH-9 & $12,81 \mathrm{a}$ & $35,22 \mathrm{a}$ & $30,82 \mathrm{a}$ & 6,83 & $\mathrm{a}$ \\
\hline MH-11 & $12,84 \mathrm{a}$ & $35,45 \mathrm{a}$ & $31,51 \mathrm{a}$ & 7,26 & $\mathrm{bc}$ \\
\hline MH-14 & $12,93 \mathrm{a}$ & $35,93 \mathrm{a}$ & $31,36 \mathrm{a}$ & 7,37 & $\mathrm{bc}$ \\
\hline MH-15 & $12,89 \mathrm{a}$ & $35,42 \mathrm{a}$ & $31,07 \mathrm{a}$ & 7,59 & $\mathrm{bc}$ \\
\hline MH-17 & $12,77 \mathrm{a}$ & $35,44 \mathrm{a}$ & $30,43 \mathrm{a}$ & 7,64 & bc \\
\hline Bima Provit A-1 & $13,29 \mathrm{a}$ & $36,11 \mathrm{a}$ & $30,44 \mathrm{a}$ & 7,69 & $\mathrm{bc}$ \\
\hline Bima 13Q & $13,12 \mathrm{a}$ & $37,13 \mathrm{a}$ & $32,82 \mathrm{a}$ & 8,42 & $\mathrm{c}$ \\
\hline BISI-2 & $12,94 \mathrm{a}$ & $36,44 \mathrm{a}$ & $32,99 \mathrm{a}$ & 8,36 & c \\
\hline
\end{tabular}

Keterangan: Angka dalam satu kolom diikuti oleh huruf yang sama tidak berbeda nyata pada berdasarkan uji Duncan's pada taraf $5 \%$.

Tabel 5. Rekapitulasi uji F dari 10 jagung hibrida harapan Madura dengan 3 varietas pembanding pada 2 musim

\begin{tabular}{|c|c|c|c|}
\hline \multirow{2}{*}{ Parameter Pengamatan } & \multicolumn{3}{|c|}{ KT } \\
\hline & Genotip & Musim & $(\mathrm{GxM})$ \\
\hline Tinggi tanaman & $830,12^{*}$ & $2677,81 * *$ & $541,2 \mathrm{tn}$ \\
\hline Tinggi tongkol utama & $117,34 * *$ & $678,43 * *$ & $321,58 \mathrm{tn}$ \\
\hline Diameter batang & $6,76 * *$ & $76,21 * *$ & $26,43 \mathrm{tn}$ \\
\hline Umur muncul tassel & $19,91 \mathrm{tn}$ & $123,42 * *$ & $23,42 \mathrm{tn}$ \\
\hline Umur muncul rambut & $44,27 *$ & $236,21 * *$ & $231,14 \mathrm{tn}$ \\
\hline Umur panen & $136,15 * *$ & $242,57 * *$ & $241,66 \mathrm{tn}$ \\
\hline Bobot 4 tongkol & $653,21 *$ & $158,21 * *$ & $87,21 \mathrm{tn}$ \\
\hline Bobot 4 biji tongkol & $89,03 \mathrm{tn}$ & $978,21 * *$ & $442,98 \mathrm{tn}$ \\
\hline Panjang tongkol & $24,76 *$ & $74,24 * *$ & $6.23^{*}$ \\
\hline Diameter tongkol & $42,88 * *$ & $241,21 * *$ & $129,87 \mathrm{tn}$ \\
\hline Jumlah baris biji tongkol & $24,39 \mathrm{tn}$ & $98,24 * *$ & $34,29 \mathrm{tn}$ \\
\hline Jumlah biji per baris & $21,77 \mathrm{tn}$ & $432,29 * *$ & $29,55 \mathrm{tn}$ \\
\hline Bobot 100 biji & $22,19 *$ & $87,34 * *$ & $21,22 *$ \\
\hline Produksi per hektar & $66,76 *$ & $1213,43 * *$ & $9,24 * *$ \\
\hline
\end{tabular}

\section{Heritabilitas (daya waris)}

Heritabilitas suatu karakter merupakan proporsi besaran ragam genetik terhadap besaran total ragam genetik ditambah dengan ragam lingkungan atau dapat disebut sebagai proporsi besaran ragam genetik terhadap besaran ragam fenotip untuk untuk suatu sifat (Bekele and Rao, 2013). Heritabilitas dapat memberi gambaran apakah suatu sifat atau lebih dipengaruhi faktor genetik atau faktor lingkungan (non-genetik) (Sari et.al, 2013). Nilai heritabilitas dalam arti luas jagung hibrida harapan Madura untuk karakter yang dievaluasi berkisar antara 0,22 - 0.61. Berdasarkan kriteria heritabilitas, karakter jagung hibrida harapan Madura memiliki kriteria sedang sampai tinggi. Karakter yang memiliki nilai heritabilitas tinggi adalah tinggi tongkol utama, diameter batang, umur muncul tassel, umur muncul rambut, bobot 4 tongkol, bobot 4 biji tongkol, panjang tongkol, diameter tongkol, jumlah baris biji tongkol, dan jumlah biji per baris. Karakter yang memiliki nilai heritabilitas tinggi adalah tinggi tanaman, umur panen, dan produksi per hektar.

Karakter dengan nilai duga heritabilitas tinggi menunjukkan bahwa faktor genetik lebih berperan dalam menentukan variasi fenotip antar genotip dibandingkan faktor lingkungan (Anshuman et. al., 2013). Seleksi pada karakter tersebut memiliki peluang kemajuan genetik yang tinggi karena sifat yang diamati dikendalikan secara kuat oleh faktor genetik sehingga akan diwariskan kepada keturunannya (Barmawi, 2013) dan seleksi pada karakter yang mempunyai nilai heritabilitas tinggi bisa dilakukan pada generasi awal (Olakojo and Olaoye, 2011). 
Tabel 6. Nilai Heritabilitas dalam arti luas

\begin{tabular}{lrrrc}
\hline \multicolumn{1}{c}{ Parameter Pengamatan } & $\sigma^{2} \mathrm{~g}$ & \multicolumn{1}{c}{$\sigma^{2} \mathrm{e}$} & \multicolumn{1}{c}{$\sigma^{2} \mathrm{p}$} & Heritabilitas \\
\hline Tinggi tanaman & 56,21 & 47,88 & 104,09 & 0,54 (Tinggi) \\
Tinggi tongkol utama & 29,73 & 39,41 & 69,14 & 0,43 (Sedang) \\
Diameter batang & 0,02 & 0,07 & 0,09 & 0,23 (Sedang) \\
Umur muncul tassel & 7,49 & 14,54 & 22,03 & 0,34 (Sedang) \\
Umur muncul rambut & 7,34 & 10,14 & 17,48 & 0,42 (Sedang) \\
Umur panen & 10,21 & 9,05 & 19,26 & 0,53 (Tinggi) \\
Bobot 4 tongkol & 431,76 & 621,31 & 1053,07 & 0,41 (Sedang) \\
Bobot 4 biji tongkol & 254,44 & 516,59 & 771,03 & 0,33 (Sedang) \\
Panjang tongkol & 15,87 & 56,27 & 72,14 & 0,22 (Sedang) \\
Diameter tongkol & 2,34 & 4,97 & 7,31 & 0,32 (Sedang) \\
Jumlah baris biji tongkol & 1,58 & 3,87 & 5,45 & 0,29 (Sedang) \\
Jumlah biji per baris & 23,39 & 32,30 & 55,69 & 0,42 (Sedang) \\
Bobot 100 biji & 22,51 & 26,42 & 48,93 & 0,46 (Sedang) \\
Produksi per hektar & 3,45 & 2,21 & 5,66 & 0,61 (Tinggi) \\
\hline Kedung
\end{tabular}

Keterangan : $\sigma^{2} g$ = ragam genetik; $\sigma^{2} \mathrm{e}=$ ragam lingkungan; $\sigma^{2} \mathrm{p}=$ ragam fenotip

Tabel 7. Seleksi indeks untuk menentukan jagung hibrida harapan terbaik

\begin{tabular}{lrrrrrrrrr}
\hline & \multicolumn{1}{c}{ Genotip } & \multicolumn{1}{c}{ Nilai fenotip yang sudah distandarisasi } & \multicolumn{1}{c}{ Nilai } \\
\cline { 2 - 8 } & $\mathrm{X}_{1}$ & \multicolumn{1}{c}{$\mathrm{X}_{2}$} & \multicolumn{1}{c}{$\mathrm{X}_{3}$} & \multicolumn{1}{c}{$\mathrm{X}_{4}$} & \multicolumn{1}{c}{$\mathrm{X}_{5}$} & \multicolumn{1}{c}{$\mathrm{X}_{6}$} & \multicolumn{1}{c}{$\mathrm{X}_{7}$} & \multicolumn{1}{c}{$\mathrm{X}_{8}$} & Indeks \\
\hline MH-3 & 0,39 & 0,41 & 0,23 & $-0,16$ & $-0,04$ & 1,02 & 0,93 & 0,82 & 9,04 \\
MH-4 & 0,13 & 0,27 & $-0,33$ & $-0,31$ & $-0,07$ & 0,47 & 0,20 & 0,32 & 3,46 \\
MH-5 & $-0,44$ & $-0,27$ & $-0,40$ & $-0,37$ & $-0,45$ & $-0,88$ & $-0,73$ & 0,13 & $-1,46$ \\
MH-6 & $-0,29$ & $-0,09$ & $-0,33$ & $-0,18$ & 0,21 & $-1,40$ & $-0,84$ & $-1,09$ & $-11,51$ \\
MH-8 & 0,02 & 0,16 & $-0,40$ & 0,02 & 0,15 & 0,26 & 0,02 & $-0,81$ & $-3,62$ \\
MH-9 & 0,07 & 0,21 & 0,10 & 0,13 & 0,22 & 0,07 & $-0,02$ & $-0,97$ & $-5,05$ \\
MH-11 & $-0,25$ & $-0,18$ & $-0,40$ & 0,27 & 0,23 & $-0,19$ & $-0,68$ & $-0,42$ & $-5,72$ \\
MH-14 & $-0,20$ & $-0,14$ & $-0,37$ & $-0,11$ & $-0,25$ & 0,04 & 0,11 & $-0,28$ & 0,52 \\
MH-15 & $-0,31$ & $-0,01$ & 0,03 & $-0,11$ & $-0,36$ & $-0,10$ & $-0,05$ & 0,00 & 1,56 \\
MH-17 & $-0,21$ & 0,05 & $-0,10$ & $-0,20$ & $-0,33$ & 0,25 & $-0,02$ & 0,06 & 2,71 \\
Bima Provit A-1 & $-0,21$ & $-0,24$ & 0,10 & $-0,35$ & $-0,42$ & $-0,34$ & 0,16 & 0,13 & 2,91 \\
Bima 13Q & 0,34 & 0,42 & 0,80 & 0,37 & 0,04 & 0,26 & 0,02 & 1,06 & 4,22 \\
BISI-2 & 0,98 & 1,03 & 0,93 & 0,99 & 1,06 & 0,51 & 0,98 & 0,99 & 1,13 \\
\hline
\end{tabular}

Keterangan : $X_{1}=$ tinggi tanaman; $X_{2}=$ tinggi tongkol utama; $X_{3}=$ diameter batang; $X_{4}=$ umur muncul rambut; $X_{5}=$ umur panen; $\mathrm{X}_{6}=$ panjang tongkol; $\mathrm{X}_{7}=$ diameter tongkol; $\mathrm{X}_{8}=$ produksi per hektar

\section{Seleksi indeks}

Karakter yang digunakan dalam perhitungan seleksi indeks tergantung pada heritabilitas dan nilai ekonomis parameter tersebut (Gazal et.al., 2017). Pada penelitian ini yang digunakan dalam perhitungan seleksi indeks adalah tinggi tanaman, tinggi tongkol utama, diameter batang, umur muncul rambut, umur panen, panjang tongkol, diameter tongkol, dan produksi per hektar. Delapan parameter digunakan dalam perhitungan seleksi indeks berdasarkan atas hasil uji $\mathrm{F}$, dimana tinggi tanaman, tinggi tongkol utama, diameter batang, umur panen, panjang tongkol, dan produksi perhektar berbeda sangat nyata pada taraf $1 \%$. Umur muncul rambut dan panjang tongkol berbeda nyata pada taraf $5 \%$, sehingga seleksi pada 8 parameter tersebut sangat efisien.

Berdasarkan atas tujuan penelitian adalah untuk memperoleh varietas berdaya hasil tinggi dan berumur pendek, maka parameter produksi per hektar dan umur pendek menjadi karakter utama dalam kriteria seleksi. Produksi per hektar dan umur panen merupakan parameter yang memiliki nilai ekonomis tinggi. Pemberian bobot didasarkan pada tujuan utama seleksi dan nilai ekonomis masing-masing karakter (Olievera et al., 2014). Umur panen diberi bobot negatif empat karena parameter ini penting dan merupakan tujuan seleksi yaitu memperoleh varietas dengan umur pendek. Produksi per hektar diberi bobot empat karena merupakan salah satu tujuan seleksi, yaitu memperoleh varietas yang berproduksi tinggi serta memiliki nilai ekonomis tinggi, sehingga diperoleh model perhitungan seleksi indeks sebagai berikut :

$$
I=-1 X_{1}-X_{2}+X_{3}-2 X_{4}-4 X_{5}+3 X_{6}+3 X_{7}+4 X_{8}
$$


Tabel 7 menunujukkan informasi bahwa ada 2 jagung hibrida harapan Madura yang memiliki nilai seleksi indeks tinggi yaitu MH-3 dan MH-4 dengan nilai indeks 9,04 dan 3,46. Hibrida harapan Madura MH-3 mempunyai nilai seleksi indeks di atas tiga varietas pembanding yaitu Bima Provit A-1, Bima 13Q dan BISI-2. Hibrida harapan Madura MH-4 mempunyai nilai seleksi indeks di atas dua varietas pembanding yaitu Bima Provit A-1 dan BISI-2.

Nilai seleksi indeks yang tinggi pada kedua jagung hibrida harapan Madura dipengaruhi oleh nilai tengah untuk parameter umur panen yang cenderung genjah masingmasing sebesar 86,46 dan 85,97. Nilai tengah untuk parameter produksi per hektar tinggi pada dua jagung hibrida harapan Madura tersebut yaitu sebesar 8,23 dan 7,84. Berdasarkan nilai seleksi indeks, maka dapat disimpulkan bahwa hibrida harapan Madura terbaik adalah MH-3 dan MH-4.

\section{KESIMPULAN}

Sepuluh jagung hibrida harapan yang diuji memiliki perbedaan penampilan, umur panen, potensi produksi yang berbeda dengan tiga varietas pembanding. Hasil pengujian gabungan pada dua musim menunjukkan bahwa ada interaksi antara perlakuan genotip dengan musim pada karakter panjang tongkol, bobot 100 biji, dan produksi per hektar. Nilai heritabilitas dalam arti luas jagung hibrida harapan Madura untuk karakter yang dievaluasi berkisar antara $22-61 \%$. Hasil dari nilai seleksi indeks terboboti menunjukkan bahwa jagung hibrida harapan Madura yang memiliki seleksi indeks tertinggi adalah MH-3 dan MH-4.

\section{DAFTAR PUSTAKA}

Amzeri, A., 2009. Penampilan lima kultivar jagung Madura. Jurnal Agrovigor. 2(1) : $23-30$.

Amzeri, A. 2015. Dasar-dasar pemuliaan tanaman. UTM Press, Bangkalan.

Anshuman, V., Dixit, N., Dipika, D., Sharma, S. and Marker, S., 2013. Studies on heritability and genetic advance estimates in maize genotypes. Bioscience Discovery, 4(2):165-168.
Barmawi, M., N. Sa'diyah dan E. Yantama. 2013. Kemajuan genetik dan heritabilitas karakter agronomi kedelai (Glycine max [L.] Merrill) generasi F2 persilangan wilis dan Mlg2521. Prosiding Semirata FMIPA Universitas Lampung.

Bekele, A and Rao, T. N., 2014. Estimates of heritability, genetic advance and correlation study for yield and it's attributes in maize (Zea mays L.). Journal of Pant Science. 2 (1) : 1-4.

BPS, 2013. Produktivitas Jagung Jawa Timur. http://Jatim.bps.go.id/ tgl 23 juli 2014.

Falconer, D. S. 1964. Introduction to Quantitative Genetics. The Ronald Press, New York.

Gazal, A., Nehfi., F.A., Lone, A.A., Dar, Z.A., and Wani, M.A., 2017. Smith hazel selection index for the improvement of maize inbred lines under water stress conditions. International journal of pure \&applied bioscience. 5(1): 72-81.

Kasryno, F., Effendi P, Suyamto dan M.O. Adnyana, 2007. Gambaran Umum Jagung Indonesia. Pusat Penelitian dan Pengembangan Tanaman Pangan. 474 - 497.

Olakojo, S. A. And Olaoye, G., 2011. Correlation and heritability estimates of maize agronomic traits for yield improvement and Striga asiatica (L.) kuntze tolerance. African Journal of Plant Science. 5(6) : 365-369.

Olievera, R.L., Pinho, R.G.V., Ferreira, D.F., Pires, L.P.M., and Melo, W.M.C., 2014. Selection indekx in the study of adaptability and stability in maize. The scientific world journal. 1-6.

Roesmarkam, S., F. Arifin, S.Z. Sa`adah, Abu dan Robi in. 2006. Usulan pemutihan varietas lokal jagung Madura Manding, Talango dan Guluk-guluk. Balai Pengkajian Teknologi Pertanian Jawa Timur.

Sari, L.W., Nugrahaeni, N., Kuswanto, dan Basuki, N., 2013. Interaksi genotipe $\mathrm{x}$ lingkungan galur-galur harapan kedelai (Glycine max (L)). Jurnal Produksi Tanaman. 1 (5) : $434-441$.

Trustinah dan Iswanto, R., 2013. Pengaruh interaksi genotipe dan lingkugan terhadap hasil kacang hijau. Penelitian Pertanian Tanaman Pangan. 32 (1) : 3642. 